\title{
Образная символика с компонентом национальных блюд у украинцев, сербов и хорватов
}

\author{
А. В. САВЧЕНКО, М. С. ХМЕЛЕВСКИЙ \\ Department of Slavic Languages and Literatures, National Chengchi University \\ No. 64, Sec. 2, Zhinan Rd., 116, Wenshan District, TW-11605 Taipei City \\ Кафедра славянской филологии, Санкт-Петербургский государственный университет, \\ Университетская наб., д. 11, RU-199034 Санкт-Петербург \\ E-mail: savchenko75@mail.ru, chmelevskij@mail.ru
}

(Received: 25 February 2017; accepted: 3 April 2017)

\begin{abstract}
The traditions and stereotypes of perception and imagination of different dishes belonging to different national Slavonic cuisines could be considered as a special cultural and linguistic formation, a special layer. The article presents some of the stereotypes of "national menus" and their reflections in some Slavonic languages, including the phraseological level, especially in the culture of Ukrainians, Serbs, and Croats. Culinary and "cooking" metaphors often become the basis for creating expressivity.

Keywords: Slavonic languages, phraseology, Ukrainian, Serbian, Croatian, stereotypes, cultural values, idioms, proverbs
\end{abstract}

Одним из неотъемлемых элементов культуры каждого народа является его национальная кухня (как одно из свидетельств тому - наличие разнообразных «этнических» ресторанов «национальных кухонь»), более того, в известном смысле кулинарное искусство является предметом гордости каждого этноса, вкусовые пристрастия и рецепты национальных блюд передаются из поколения в поколение. Они отражают природные условия, в которых живут эти народы, а также их менталитет, представления о прекрасном и отвратительном: съедобном и несъедобном, вкусном и невкусном, своем и чужом. М. Л. Ковшова отмечает, что пищевой код, в силу своей значимости в развитии и жизнедеятельности человека, является одним из базовых кодов культуры (КовшовА 2013: 232-253).

Элементы национальной кухни глубоко вошли в культуру славянских народов - фольклор, песни, литературу, не зная которых трудно до конца понять пусть даже близкий славянский, но все же другой народ. То, что национальная кухня представляет собой культурную ценность, говорят нам данные языков. Она прочно «укоренилась» в языке - лексике и, что представляет для нас наибольший интерес, фразеологии: в устойчивых сравнениях и метафорических переносах, т. е. именно там, где как раз наиболее ярко проявляются сходства и различия славянских народов в их представлениях о еде. Это доказывается, в частности, и богатым идиоматическим (фразеологическим и паремиологическим) материалом (НиколАЕВА 2015: 153). 
Данная тематика привлекает внимание как культурологов, этнографов, с одной стороны, так и славистов - с другой. С филологической точки зрения, «кулинарная лексика», репрезентирующая т. н. «кулинарный (пищевой, гастрономический) код», достаточно подробно исследована и описана на материале русского языка. В области фразеологии ей, в частности, посвящены работы О. А. Димитриевой, В. М. Мокиенко, А. Хрняк, М. Л. Ковшовой и Е. К. Николаевой (см. ДимитриевА 2006, HRNJAK 2007, МокиЕнко 2008, КовшовА 2013, НикоЛАЕВА 2016), в области лексики - работы И. С. Лутовиновой, О. А. Дормидонтовой (см. Лутовинова 2005, ДормитонтовА 2011) и многих других. Различным аспектам отражения «пищевого кода» в языке, например, посвящена работа Е. А. Юриной (см. ЮринА 2013). Однако научно-исследовательская база по другим славянским языкам пока представляется нам далеко неполной: за исключением этнографических работ и трудов в области фольклора мы столкнулись с проблемой недостаточного научного освещения этнических стереотипов, связанных с кулинарным кодом, и их реализации в современных языках. В этом аспекте можно, в частности, отметить работу А. Хрняк, посвященную сопоставлению «кулинарных элементов» в русской и хорватской фразеологии (см. HRNJAK 2007). Собранный материал из восточных и южных славянских языков представлен как по отдельным языкам, так и в сравнительно-сопоставительном аспекте в лингвистическом ключе на культурологическом и этнографическом фоне.

В украинской культуре стол без хлеба - не стол: без хліба половина обіду; не буде хліба, не буде й обіда. Однако здесь следует отметить, что русские под «хлебом» понимают совершенно другой его сорт в отличие от остальных славян. Если в ассоциативном ряду русского на первом месте стоит хлеб черный, ржаной в форме кирпича или (реже) черный круглый, а также в виде корочки, куска хлеба, сухарика, то для украинца в воображении предстает пышный, мягкий белый, пшеничный и круглый.

Традиционный круглый пшеничный хлеб украинцы называют паляниця (от паля 'острый шест, кол, на который его подвешивают к потолку'). Он издавна считался священным и символизировал счастье и благополучие: паляниця - хлібові сестриця. Украинская народная культура богата приметами, в которой хлеб, в том числе и паляниця, предстает своеобразным фольклорномифологическим персонажем, например, украинцы верят, что нельзя оставлять недоеденный кусок хлеба на столе, так как это значит - оставлять свое счастье, это к беде и болезни; нельзя отдавать свой кусок хлеба доедать другому - значит, свое счастье отдавать; нельзя другому позволять есть хлеб у себя за спиной - значит, «он съест твою силу» и т. д.

Разница в представлениях у русских и украинцев вполне объяснима климатическими условиями (ср. рус. ржаной хлеб - всему голова и укр. яка пшеницяя - така й паляниця).

Вообще, богатство, изобилие и многообразие украинского стола, в отличие, например, от русских паремий (где подчеркивается довольствование малым), с тем же самым многообразием отражается в украинском народном 
творчестве: Ми люди прості: хліба скибку, сяку-таку рибку, борща гіршочок, сала шматочок, солі дрібочок та горілочки чарчину, заморюсь я собі, чхну та й знову почну.

Борщ та каша - ̈̈жа наша; борщ - всьому голова, - говорят украинские поговорки, в которых ярко иллюстрируются расхождения в традиционных предпочтениях других восточных славян - например, у русских. Так, если щи можно назвать «брендом» русской культуры, то тем же, несомненно, является борщ для украинского народа, который переняли другие соседние народы - русские, поляки, белорусы, литовцы. Борщ - основное первое блюдо украинской кухни - известен со времен Киевской Руси, он готовится из свеклы, которая придает ему характерный красный цвет, с добавлением картофеля, фасоли, моркови, капусты, лука, помидоров, мяса, колбасы, маленьких вареников с начинкой (укр. вушка) или грибов, подается со сметаной и «пампушками» - сладкими булочками из пшеничного теста, политыми подсолнечным маслом с чесноком (в украинском языке даже есть устойчивое выражение маятися як пампушка у маслі 'томиться, испытывать тоску, скуку от безделия').

Украинский борщ (кстати, в отличие от русских щей, которые ассоциируются с бедностью, ср., например, голодному Федоту любые щии в охоту; щзи да щзи - захочешь лапши) является символом богатства, сытой жизни, изобилия (в борщ может входить до 20 компонентов в зависимости от региона и способов приготовления: чого не люблю, того в борщ не кришу). Эта «сытость» довольно часто иронично обыгрывается в украинских пословицах и поговорках: борщ та капуста - хата не пуста; по самісинкі боки набрався борщу; смачні борщ та каша, але як би ще шматок м'яса; я люблю усякий борш, аби з м'ясом; борщ без каші - удовець, каша без борща - вдова; жонатий борщ - значит, с кашей. Борщ - гордость украинского стола (щзо-небудь - аби борщ; без докладу борщз не смачный; немає в світі як той борщз: хоч поганий, та до біса; свій борш несолоний ліпший, як чужа юшка).

Заимствовав у украинцев в XVI веке борщ, поляки сформировали свой «фразеологический взгляд» на это блюдо: борщ стал основой для ряда устойчивых сравнений, используемых в живой разговорной речи, как правило, с отрицательной коннотацией, например, tani jak barszcz, cienki jak barszcz 'скучный, предсказуемый'; это же выражение может использоваться в контекстах с семантикой 'о чем-л. или ком-л. малоинтересном, не имеющем значения’. Слабый человек в польском также сравнивается с борщом, как его представляют поляки: staby jak barszcz. Подобный контраст «положительного» и «отрицательного» в сопоставлении с украинским, вероятно, обусловлен принципиальным отличием украинского (и русского варианта) борща от польского, где преобладает бульон, в нем практически нет гущи, он менее наваристый, в отличие от украинского. Кстати, а вот блюдо старопольской кухни - черный суп, т. е. бульон с добавлением утиной, куриной, кроличьей крови, вероятно, благодаря своей необычной «кровавой» составляющей, породил фразеологизм czarna polewka 'отказ девушки от предложения руки и 
сердца «престарелым» ухажерам'. Фразеологизм чаще встречается в формах podać czarna polewkę (букв. «подать черный суп») - т. е. 'не принять чьего-л. предложения выйти замуж'; dostać czarnq polewke (букв. «получить черный суп») - наоборот - 'получить отказ'.

В данной связи, но уже с другим компонентом, стоит вспомнить древнюю украинскую традицию, когда девушки в деревнях в шутку выносили из дома тыкву в знак отказа молодому человеку на его предложение руки и сердца. Традиция канула в лету, зато до сих пор в современном украинском языке живут такие фразеологизмы, как дати/піднести/niдсунути (печеного) гарбуза (т. е. 'тыквы') - 'отказать тому, кто пришел свататься' и, наоборот, дiстати/з'їсти/покуштувати гарбуза 'получить отказ во время сватовства'. Эта традиция и такой образ тыквы в украинской культуре породил в языке ряд легких ироничных ругательств: гарбуз твоїй матері!; гарбуз батькові твоєму печений! Поэтому до сих пор в народной речи можно услышать предостережения об отказе или неудаче вообще: глядіть, щзоб вам гарбуза не піднесли!; коли б вам тілкі гарбуз не покатився; или, наоборот, пожелания удачи: бодай вам гарбуз стелився!

Еще одним из узнаваемых украинских продуктов, составляющих часть украинской культуры, обрядов, фольклора и просто хлебосольного стола, можно назвать украинское сало, без которого трудно себе представить быт и стол украинца. Это гордость украинской национальной кухни: сало - не велика слава, а все ж ласощі. Сало - свиной жир, который употребляется в пищу в свежем, соленом, копченом и жареном виде. Говоря об украинском сале, мы прежде всего имеем в виду соленое и копченое, приготовленное десятками различных способов. Вполне закономерно, что такая популярность сала в украинской традиционной культуре не могла не отразиться в языке. В нем с иронией обыгрывается известная идиома Вам тут шо, медом/салом намазано?, с помощью которой выражается недоумение по поводу слишком большого количества людей в одном месте или неудовольствие самим фактом частого присутствия человека в каком-л. месте. Сало употребляют в пищу с хлебом, что стало основой для возникновения выражения дурне сало без хліба 'о ни к чему не годном человеке, дураке, глупом', равно как и такие устойчивые сравнения, как дурний/тупий як сало без хліба, или ироничное выражение в том же значении розумний як сало, т. е. 'глупый'.

Сало, как и борщ, также ассоциируется с достатком, изобилием и сытостью, что отражается в народном творчестве, например, живу добре: сало їм, на салі сплю, салом укриваюсь или якби мені паном бути, то б я тількі сало з салом їв. Любопытно, что в современном молодежном жаргоне в шутку обыгрывается данная метафора с фразеологизмом жити як у шоколаді в виде (як) сало в шоколадi.

Отметим, что на фоне русских паремий (типа хлеб да каша - пищуа наша) мы встречаем множество украинских паремий с компонентом «сало» с общим значением 'мечта о достатке и сытой жизни': якщо вже їсти сало, то так, щзоб по бороді текло; давайте щзо попало, як не хліб, то сало. 
Здесь же отметим, что трудно себе представить хлебосольный украинский стол без традиционных украинских вареников - отварных изделий небольшой формы, которые лепятся из пресного теста с маслом или сметаной и начинкой из рубленого мяса, тушеной капусты, печени, грибов, картофеля, творога, мака, фруктов или ягод, а затем варятся. Их вкус и калорийность также послужили основой для украинского фразеологизма с тем же представлением о достатке: жити як вареник у маслі/у сметані.

В украинском языке при характеристике человека глупого и недалекого участвует еще один «съедобный» компонент национальной кухни - галушка: ср. тупий як галушка. Подобная ассоциация возникла на основе незатейливого способа приготовления галушек - традиционного украинского блюда в виде кусочков теста, вываренных в воде и заправленных шкварками с жареным луком или сметаной, что породило в украинском языке еще одно устойчивое сравнение лежить як галушка - говорится о ленивом человеке.

Рассмотрев общекультурные и фразеологические «кулинарные пристрастия〉 украинцев, мы обратим свое внимание к южнославянскому региону, и сопоставим, какие приоритеты кухни Южной Славии являются наиболее частотными в создании народной образности. Говоря о сербах, черногорцах, хорватах, боснийских мусульманах, следует вначале отметить почти полную языковую общность, а также схожесть климатических и географических условий, в которых они проживают, а следовательно, и их национальной кухни, которая во многом, хотя далеко не всегда, их объединяет. Различия между этими народами заключаются прежде всего в религии, которую на ранних стадиях формирования данных наций они выбрали, и которая впоследствии определила различные пути их становления, культуры, традиций, образа мышления и, соответственно, национальных кулинарных пристрастий.

Не возникает сомнений, что и у южных славян - хлеб всемуголова, правда, как у всех славян без исключения. Следует также подчеркнуть одно отличие от восточных славян - хлеб в менталитете народов Южной Славии не «канонизируется» так сильно, а зачастую связывается с тяжелым трудом и бедностью: zarađivati na koricu hleba/kruha 'зарабатывать (на корку хлеба)', doći do svoga hleba/kruha 'начать зарабатывать, стать финансово независимым', uhlebiti se 'хорошо устроиться (например, в жизни)'. О необходимости хлеба в рационе человека говорит такое устойчивое сравнение, как potreban kao hleb/kruh, т. е. 'очень необходим': ovaj most je potreban Dubrovniku kao $k r u h$ 'Этот мост нужен Дубровнику как хлеб' (ср. рус. как воздух). Наличие хлеба ассоциируется с умением заработать на хлеб, о чем говорят такие расхожие в сербском и хорватском языках фраземы, как imati hleb/kruh u ruka$m a$ (букв. «иметь хлеб в руках»), т. е. 'хорошо знать свою работу, быть специалистом в какой-л. области', а вот отсутствие хлеба говорит о невозможности человека пробиться в обществе: nema u ovom gradu hleba/kruha za mene (букв. «нет в этом городе для меня хлеба»).

Восточнославянским калачам можно найти соответствия на славянском юге: pogača - круглый, обычно соленый хлеб, иногда с картофелем, овечьим 
творогом, шкварками (не по составу, а по значимости в народном сознании этот сорт хлеба можно сопоставить с тем, что украинцы называют паляниия). «Погача» глубоко вошла в культуру и фольклор южных славян: сербы, хорваты и черногорцы готовят ее на Рождество, существуют целые традиции, связанные с ней. Например, внутрь кладут монету, и кому попадается такой кусок, тот будет счастлив и здоров. Погачу готовят к рождению ребенка и кладут у его головы, чтобы он рос здоровым (в дар девам судьбы). Гости также преподносят в дар роженице свою погачу, приговаривая: Da porasne, da se oženi, da ostareje, da pobeleje, da odgleda vnuke i pravnuke (букв. «Чтобы вырос, женился, состарился, поседел и увидел внуков и правнуков»). Хорваты при завершении жатвы подбрасывали сноп, приговаривая: Bog daj tako visoku pogaču (букв. «Дай, Боже, такую высокую погачу»). Несомненно, на основе такой ассоциации с богатством и благосостоянием вошел в современный язык такой фразеологизм, как tražiti hleba pored pogače (букв. «искать хлеб, когда есть погача»), т. е. 'быть недовольным тем, что имеешь' (ср. рус. om добра добра не ищут). По традиции погачу разламывают на кусочки и угощают гостей, соседей, родственников и даже несут скоту, отсюда возник фразеологизм lomiti/jesti s kim pogaču - т. е. «делить еду пополам», который также употребляется в значении 'жить вместе'.

Примечательно, что каша давно вышла из рациона южных славян, и молодому поколению, современным носителям языка, порой это блюдо почти не знакомо, зато она часто присутствует в устойчивых сочетаниях в значениях, довольно отличных от восточнославянских. Например, motati se kao mačka oko vruće kaše (букв. «вертеться как кошка вокруг горячей каши»; ср. нем. Wie die Katze um den heißen Brei schleichen), a jesti vruću kašu вообще означает 'попасть в неловкую ситуацию', biti u istoj kaši (букв. «быть в одной каше»), т. е. 'оказаться вдвоем в одной неприятной истории' (ср. русский образ горячей каши, где это обычно вкус и достаток). А вот hladiti kašu (букв. «охлаждать кашу») - наоборот, имеет значение 'искать выход из трудной ситуации'.

Мед в сочетании с молоком издавна вызывал ассоциации богатства и изобилия (ср. рус. молочные реки и [но!] кисельные берега), например, оbеćati kome med i mleko 'обещать благосостояние' (ср. рус. золотые горы), т. е. своего рода некое стремление к идеалу, что в языке отражается в устойчивом сочетании nije sve med i mleko (букв. «не все мед и молоко»), т. е. 'нет ничего безупречного’ или očekivati med i mleko (букв. «ожидать меда и молока»), т. е. 'верить, что все получится без проблем, наилучшим образом' (HRNJAK 2007).

В благоприятном южном климате Балкан произрастает обилие овощей и фруктов, которые в качестве компонента также встречаются в сербских и хорватских фразеологизмах, но опять-таки совсем с другими ассоциациями, чем у остальных славян. Так, горячая картошка - vrući krompir, как и каша, у южных славян вызывает образ «неловкой ситуации, проблемы»: prebacivati vrući krompir komu (букв. «перебрасывать горячую картошку кому-л.») употребляется в значении 'сваливать свои проблемы/ответственность на другого’. Приведем пример употребления данного фразеологизма в контексте: 
štrajkovi u Hrvatskoj su vrući krumpir za novu vladu - букв. «забастовки в Хорватии - это горячий картофель для нового правительства».

Лук с водой для южных славян - это самая обычная и простая еда, которую можно себе только представить; в языке это «блюдо» в переносном значении употребляется для обозначения чего-л. совсем незатейливого: ovo je za mene luk $i$ voda (букв. «это для меня лук и вода»), т. е. 'очень легко, как дважды два' (сравним образ пареной репь в русской культуре: проще пареной репь, или же образ семечек: как семечки). Весьма популярен на Балканах укроп - mirodžija, который можно встретить чуть ли не в любом блюде, что послужило основой для фразеологизма u svakoj supi mirodžija (букв. «в каждом супе укроп») - говорится о том, кто лезет в чужие дела (ср. рус. в каждой бочке затычка или наш пострел везде поспел).

Разницей в климатических условиях восточных и южных славян можно объяснить значительно большее количество фруктов, вошедших в язык в переносном значении или участвующих в образовании фразеологизмов. Помимо не исконного для славян библейского jabuka razdora - «яблоко раздора», в сербском языке яблоко также ассоциируется с человеческой красотой, а именно женской, поскольку у южных славян слово jabuka - женского рода. Devojka je lepa kao jabuka (букв. «девушка красива как яблоко») - такое сравнение довольно часто можно услышать на всем пространстве Южной Славии от Белграда до Загреба. Любопытна также ассоциация, которую вызывает на Балканах айва, которая в восточнославянском сознании - довольно экзотичный фрукт, а у южных славян она символизирует уют домашнего очага, который создается в доме прежде всего женщиной, а следовательно, и сама айва ассоциируется с женщиной, хранительницей дома, вследствие чего айва, т. е. серб. dunja может употребляться в качестве ласкового обращения к любимой женщине. В данном контексте в украинской культуре мы найдем скорее сравнения с вишней или калиной.

Сладкие кулинарные изделия для южных славян по своей распространенности и популярности могут вполне заменить хлеб. Пирожное, или серб. kolač, - частый гость во фразеологических единицах: dobiti kolač 'получить большую, лучшую часть чего-л.'; uzeti svoj dio kolača 'получить выгоду'.

Одним из самых популярных кондитерских изделий на Балканах является лукум - сладкие кусочки из сахара с добавлением крахмала и орехов. Лукум, или рахат-лукум, пришел на Балканы из Турции (тур. rahat-lokum букв. «удобные кусочки»). Особое распространение он получил в Боснии, и сейчас эти разноцветные и многообразные сладости украшают местные базары и витрины магазинов, его едят вприкуску с крепким ароматным кофе. Вместе с этими сладостями в языке укореняется и турецкое по происхождению прилагательное rahatni 'спокойный, уютный, удобный'. Как и в других языках, сладкое всегда ассоциируется с прекрасной, беззаботной жизнью, за этим словом закрепилось значение блаженства, удовольствия или наслаждения, которое трудно перевести на русский язык: osjećati se rahatno 'чувствовать себя приятно, вольготно, беззаботно'; rahatno pričati ‘говорить сладкие 
речи'; U Sarajevu turist može rahatno hodati gradom 'В Сараево турист может гулять по городу, получая наслаждение', rahatno dijete 'милый ребенок'.

В настоящей статье вкратце представлены украинская, сербская и хорватская кухни, основные концепты которых прочно вошли в культуру и застыли в языках каждого из народов в виде устойчивых сравнений, фразеологизмов, пословиц и поговорок. Мы попытались выбрать из всего многообразия традиционных блюд этих народов наиболее характерные и узнаваемые, с помощью которых на кулинарном, а прежде всего - на языковом материале можно проиллюстрировать не только схожесть, но и - что более существенно - различия между разными славянскими народами как в их пристрастиях к еде, так и разности ассоциаций с продуктами питания, а также продемонстрировать варианты и различия в компонентном составе фразеологических единиц, имеющих общее значение.

\section{Литература}

БІЛОНОЖЕНКО 1993 = БІЛОНОЖЕНКО В. М. та ін. (уклад.) Фразеологічний словник української мови. Київ: «Наукова думка», 1993.

ДимитриевА 2006 = ДимитриевА О. А. Национально-культурная специфика фразеологизмов поля «Приготовление пищи и продукты питания». В кн.: Проблемы изучения и преподавания русского языка и литературы. Материалы V Международной научной конференичи. Тайбей, 2006. 45-56.

ДормитонтовА 2011 = ДоРмитонтовА О. А. Гастрономическая метафора как средство концептуализаџии мира. АКД. Тамбов, 2011.

КОВшовА 2013 = КовшовА М. Л. Лингвокультурологический метод во фразеологии. Коды культуры. Москва: «Либроком», 2013.

КУзНЕцОВА 2007 = КУзНЕцОВА И. В. Образ мака. В кн.: Проблемы языковой картины мира на современном этапе. Вып. 6. Нижний Новгород: НГПУ, 2007. 169-174.

Лутовинова 2005 = ЛутовиновА И. С. Слово о пище русской. Издание 2-е, переработанное. Санкт-Петербург: «Авалон», «Азбука-классика», 2005.

Мокиенко 2008 = Мокиенко В. М. За что себя хвалит гречневая каша? В кн.: Учистого источника родного языка. Сборник научных статей к 60-летию профессора В. И. Супруна. Волгоград: ВГПУ, «Перемена», 2008. 330-344.

МокИЕНКО-НикитинА 2007 = МокиЕнко В. М., НикитинА Т. Г. Большой словарь русских поговорок. Москва: «Олма Медиа Групп», 2007.

МоКИЕНКО-НикИТИНА 2008 = МоКИЕНКО В. М., НикИтинА Т. Г. Большой словарь русских народных сравнений. Москва: «Олма Медиа Групп», 2008.

НиколАЕВА 2016 = НиколАЕВА Е. К. Пищевые образы в устойчивых сравнениях. В кн.: МокиЕнко В. М. (ред.) Устойчивые сравнения в системе фразеологии. Санкт-Петербург-Грайфсвальд, 2016. 152-158.

ТРОФИМкинА 2005 = ТРОФИМкинА О. И. Сербохорватско-русский фразеологический словарь. Москва: «Восток-Запад», 2005.

Юрина 2013 = Юрина Е. А. Вкусные метафоры. Пищевая традиция в зеркале языковых образов. Кокшетау: КГУ им. Шокана Уалиханова, 2013.

HRNJAK 2007 = HRNJAK A. Kulinarski elementi u hrvatskoj i ruskoj frazeologiji. Rasprave 33 (2007): 197-216. 